\title{
Service-Learning as a Means to Understand Socio-Economic Privilege, Inequality, and Social Mobility
}

\author{
Mikiko Nishimura and Hitomi Yokote
}

\section{Introduction: The Challenge of Civic Engagement to Address Social Inequality in Liberal Arts EDUCATION IN AsIA}

Liberal arts education has rapidly spread in Asia over the past 20 years. According to Godwin, 44\% of the total of 161 programs outside the United States were created after 2000 and approximately 13\% (69) of

${ }^{1}$ K. A. Godwin, "The Global Emergence of Liberal Education: A Comparative and Exploratory Study" (PhD diss., Boston College, 2013), https://dlib.bc. edu/islandora/object/bc-ir:104384; K. A. Godwin, "The Worldwide Emergence of Liberal Education," International Higher Education 79 (2015): 2-4.

\footnotetext{
M. Nishimura $(\bowtie) \cdot H$. Yokote

International Christian University, Tokyo, Japan

e-mail: nmikiko@icu.ac.jp

H. Yokote

e-mail: yokohitomi@icu.ac.jp

(C) The Author(s) 2020

C. S. Sanger and N. W. Gleason (eds.),

Diversity and Inclusion in Global Higher Education, https://doi.org/10.1007/978-981-15-1628-3_7
} 
liberal arts programs in the world are found in Asia where India, Japan, and Hong Kong share half of them. ${ }^{1}$ The main reasons for this trend are three-fold. First, there has been a widespread notion that the highly specialized academic fields have limitations to tackle complexities of the global issues for which the interdisciplinary approach of liberal arts education was considered as a better alternative. Second, the twenty-firstcentury skills and competencies for innovation advocated in the international sphere ${ }^{2}$ were in line with fundamental principles of liberal arts education that emphasize critical thinking, moral and civil character, and use of knowledge to improve the world. ${ }^{3}$ Third, the "international" liberal arts education has become one "business model" in East Asia to attract international students and to meet the global market needs. ${ }^{4}$

While civic engagement with social equity and justice has been one of the core values of liberal arts education in North America, what is distinctive about the rapid expansion of liberal arts education programs in Asia is its heavy emphasis on pragmatic motivation initially to catch up with the West and more recently to become a global leader. Large-visioned ideals, moral purpose as members of a civil society, criticism against moral emptiness of modern sciences featured by the US liberal arts traditions are largely absent or at best only implicitly embedded. ${ }^{5}$ Yang claims that the East Asian societies have had a strong catch-up mind-set with the West

${ }^{2}$ K. Ananiadou and M. Claro, "2lst Century Skills and Competencies for New Millennium Learners in OECD Countries" (OECD Education Working Papers No. 41, 2009); OECD, The Future of Education and Skills: Education 2030 (Paris: OECD, 2018).

${ }^{3}$ R. Chopp, "Remaking, Renewing, Reimagining the Liberal Arts College Takes Advantage of Change," in Remaking College: Innovation and the Liberal Arts, edited by R. Chopp, S. Frost, and D. H. Weiss (Baltimore: Johns Hopkins University Press, 2014), 13-24.

${ }^{4}$ A. Yonezawa and M. Nishimura, "Revisiting Key Values, Roles, and Challenges of Liberal Arts Education in East Asia," in Liberal Arts Education and Colleges in East Asia: Possibilities and Challenges in the Global Age, edited by I. June, M. Nishimura, and T. Sasao (Singapore: Springer, 2016), 125-136.

5 J. Buchler, "Reconstruction in the Liberal Arts," in A History of Columbia College on Morningside, edited by D. C. Miner (New York: Columbia University Press, 1954); R. M. Hutchins, The Higher Learning in America (New Haven: Yale University Press, 1968); H. C. King, "What the College Stands for," Association of American Colleges Bulletin III, no. 1 (1917): 24; A. Meiklejohn, The Liberal College (Boston: Marshall Jones, 1920); W. Summerscales, Affirmation and Dissent (New York: Teachers College Press, 1970). 
that has led them to focus on Western practicality, rather than consider moral underpinnings of educational systems. ${ }^{6}$

Furthermore, the neoliberal outlook and focus on "practicality" in higher education in Asia has been intensified by the recent trend of internationalization of higher education literatures with a strong focus on numerical trends of student mobility, diversity and flexibility of programs, the university ranking, and quality assurance. ${ }^{7}$ Internationalization efforts in higher education institutions tend to aim at preparing students for the global economy where the focus is on developing "global competencies" that would enable students to become internationally mobile and readily employable in a variety of cultural contexts. ${ }^{8}$ Fostering citizenship, social equality, inclusive society, and common good seem to be a lost agenda in higher education in many Asian contexts.

At the same time, social inequality in Asia is expanding ever more rapidly than before and in any other region. While the East Asia and Pacific region have the lowest income inequality of the world, the Gini coefficient rose from 32.7 to 38.1 between 1990 and 2014 with the largest magnitude of rise in the world during this period. ${ }^{9}$ Empirical evidence shows that while equal distribution of educational opportunity generally contributed to reducing income inequality, higher per capita income, greater openness to international trade, and faster technological progress made both income and education distribution unequal. ${ }^{10}$

${ }^{6}$ R. Yang, "The East-West Axis? Liberal Arts Education in East Asian Universities," in Liberal Arts Education and Colleges in East Asia: Possibilities and Challenges in the Global Age, edited by I. June, M. Nishimura, and T. Sasao (Singapore: Springer, 2016), 27-38.

${ }^{7}$ S. J. Chen, "Shifting Patterns of Student Mobility in Asia," Higher Education Policy 25, no. 2 (2012): 207-224; K. H. Mok and K. M. Yu, Internationalization of Higher Education in East Asia: Trends of Student Mobility and Impact on Education Governance (New York: Routledge, 2014); M. Shah and D. T. N. Quyen, eds. The Rise of Quality Assurance in Asian Higher Education (Cambridge: Chandos Publishing, 2017).

${ }^{8}$ F. Atkas, K. Pitts, J. C. Richards, and I. Silova, "Institutionalizing Global Citizenship: A Critical Analysis of Higher Education Programs and Curricula," Journal of Studies in International Education 21, no. 1 (2017): 65-80.

${ }^{9}$ P. Andersson, "Inequality in Asia and the Pacific" (Presentation, Interregional Expert Group Meeting on Placing Equality at the Center of Agenda 2030, Santiago, June 2018), https://www.cepal.org/sites/default/files/presentations/s1_3._pandersson.escap_.pdf.

${ }^{10} \mathrm{~J}$. Lee and H. Lee, "Human Capital and Income Inequality" (ADBI Working Paper Series No. 810, Asian Development Bank Institute, Tokyo, 2018). 
Fast income growth and rapid progress of globalization and technological change seem to have accelerated income inequality in Asia over the past two and half decades.

Given this trend, how does liberal arts education address social inequality and inclusion at local and global levels in Asia? In this chapter, we attempt to discuss service-learning programs to examine the challenges and potential of liberal arts education in Asia to enhance civic engagement and greater awareness of socio-economic diversity in the international/intercultural dimension. In the next section, we discuss the linkage between service-learning and civic engagement, and the controversy over higher education's role in reproducing social inequality. Section "ICU's International Service-Learning and Its Impact on Students" presents the case of international service-learning programs at International Christian University (ICU) in Japan to examine the program's learning outcomes and challenges. Finally, section "Discussion: Missing Link Between Moral Awareness and Civic Engagement" will critically reflect on the potential and future direction of service-learning programs in liberal arts education to address social inequality in Asian contexts.

\section{Service-Learning Program: Peril or Promise?}

There has been a prolonged debate in Sociology of Education over whether education in a meritocratic society generates chances for upward social mobility or reproduces social inequality. ${ }^{11}$ Given the high tuition in small-sized private liberal arts colleges in the United States, investing in liberal arts higher education is often regarded as a luxury, out of touch, elitist, ineffective, and well past in use. ${ }^{12}$ Previous studies also looked into positive comprehensive outcomes of liberal arts education in self-efficacy, leadership skills, civic engagement, and global connections. ${ }^{13}$

${ }^{11}$ A. R. Sadovnik, ed. Sociology of Education: A Critical Reader, 2nd ed. (New York: Routledge, 2010).

${ }^{12}$ J. Logan and J. Curry, "A Liberal Arts Education: Global Trends and Challenges," Christian Higher Education 14, nos. 1/2 (2014): 66-79; C. Rowen, "So Much More Than Salary: Outcomes Research in Liberal Arts," New Direction for Institutional Research 169 (2016): 51-60.

${ }^{13}$ E. T. Pascarella, G. C. Wolniak, T. A. D. Seifert, T. M. Cruce, and C. F. Blaich, "Liberal Arts Colleges and Liberal Arts Education," ASHE Higher Education Report 31, no. 3 (2005): 1-146; Rowen, "So Much More Than Salary." 
Service-learning is a pedagogy designed to transform the role of higher education from an elitist reproduction of privileges and social inequality to one of redressing social inequality through civic and community engagement at local and global levels. Service-learning is typically defined in the United States as "a credit-bearing, educational experience in which students participate in an organized service activity that meets identified community needs and reflect on the service activity in such a way as to gain further understanding of course content, a broader appreciation of the discipline, and an enhanced sense of civic responsibility." 14 In Asia, however, there exist many service-learning programs including but not limited to non-credit bearing programs, short-term summer international programs, and a graduation requirement without bearing a credit. In this context, service-learning is simply defined as "intentionally structured activities that engage students in social services to solve problems encountered by community members." 15

There are numerous service-learning practices in higher education in North America over the past four decades or more and their outcomes have been documented in abundant peer-reviewed journal articles and books. Service-learning is expected for students to gain insight about their personal strengths and identity, to learn about the realities of inequality, and to increase their empathy and sense of social responsibility and social justice. ${ }^{16}$ Service-learning has been found to be associated with a host of positive outcomes, including greater sensitivity and empathy, increased commitments to social justice, improved cultural competence or multicultural skills, and stereotype reduction. ${ }^{17}$

The learning outcomes of service-learning have also been reported to vary depending on the program type and student demographics.

${ }^{14}$ R. G. Bringle and J. A Hatcher, "A Service-Learning Curriculum for Faculty," Michigan Journal of Community Service Learning 2, no. 1 (1995): 112.

${ }^{15}$ K. Chan, E. Ng, and C. C. Chan, "Empowering Students Through Service-Leaning in a Community Psychology Course: A Case in Hong Kong," Journal of Higher Education Outreach and Engagement 20, no. 4 (2016): 25-35.

${ }^{16}$ K. R. Brewster, "Transformative and Transformed: Examining the Critical Potential of Service-Learning Positional Identities," Equity o Excellence in Education 51, nos. 3-4 (2018): 347-361.

${ }^{17}$ J. Conner and J. Erickson, "When Does Service-Learning Work? Contact Theory and Service-Learning Courses in Higher Education," Michigan Journal of Community Service Learning 23, no. 2 (2017): 53-65. 
For example, Brown et al. found that the service-learners in autonomyoriented placements that aimed at assisting the recipient with a partial solution had more positive attitudes toward social equality than did a control group and those in dependency-oriented programs that provided a full solution to recipients' needs. ${ }^{18}$ Another study by Conner and Erickson shows that service-learning with more attention to quality and engaged contact with communities had a more positive impact on reducing students' overall color-blindness and improving their awareness of blatant racial issues. ${ }^{19}$ They also point out that the impact was different by race and gender whereby non-white and male students improved their awareness significantly more than their counterparts.

Service-learning is more of the recent trend in Asia where Christian universities were the main driving force to adopt service-learning programs in the late 1990s to the 2000s. The Service-Learning Asia Network (SLAN) was established in 2002 and has held an annual meeting every year since. In Asia, service-learning has been reported to impact students' interpersonal, interactional, and behavioral changes. ${ }^{20}$ Yang et al. indicated that service-learning impacts students' conceptions of self as leaders who promote and uphold long-term benefits for community members and their peers. ${ }^{21}$ They further argue that international service-learning has the potential for supporting students' self-exploration by giving them opportunities to incorporate moral, cultural, and leadership values into their conceptions of self.

Nevertheless, since the late 2000 s, critical perspectives on servicelearning have grown to argue against the benefits of traditional "charitymode" service-learning. These critiques insist that it does not create

${ }^{18}$ M. A. Brown, J. D. Wymer, and C. S. Cooper, "The Counter-Normative Effects of Service-Learning: Fostering Attitudes Toward Social Equality Through Contact and Autonomy," Michigan Journal of Community Service Learning 23, no. 1 (2016): 37-44.

${ }^{19}$ Conner and Erickson, "When Does Service-Learning Work?".

${ }^{20}$ Chan, $\mathrm{Ng}$, and Chan, "Empowering Students Through Service-Leaning in a Community Psychology Course."

${ }^{21}$ M. Yang, L. Y. Y. Luk, B. J. Webster, A. W. Chau, and C. H. K. Ma, "The Role of International Service-Learning in Facilitating Undergraduate Students' Self-Exploration," Journal of Studies in International Education 20, no. 5 (2016): 416-436. 
structural change in society and is distanced from social justice. ${ }^{22}$ Clifford notes that traditional service-learning is skewed toward professional skill development and perceived as a mere "product" for career advancement. ${ }^{23}$ Such service-learning programs generate depoliticized participation, simply create the mere dreaming of justice, and reproduce cognitive deficits of students that ignore the structures of power, privilege, and oppression that made them lucky enough to get to do service. ${ }^{24}$ Critical perspectives argue that service-learning could potentially be considered exploitative, failing to provide students with a critical appreciation of the issues of power and inequality embedded in working with deprived or marginalized communities, thus reinforcing their prejudices, stereotypes, and deficit-based views cultivated by the societal context of neoliberalism. ${ }^{25}$

Critical perspectives suggest an alternative form of service-learning, often called "critical service-learning" whereby students should be supported and challenged to reflect on their own unconscious biases and stereotypical behaviors by critical reflection and reciprocity for social

${ }^{22}$ J. Clifford, "Talking About Service-Learning: Product or Process? Reciprocity or Solidarity?" Journal of Higher Education Outreach and Engagement 21, no. 4 (2017): 1-13; A. Furco, "Foreword," in Problematizing Service-Learning: Critical Reflections for Development and Action, edited by T. Stewart and N. Webster (Charlotte, NC: Information Age, 2011), ix-xi; T. Mitchell, "Traditional vs. Critical Service-Learning: Engaging the Literature to Differentiate Two Models," Michigan Journal of Community Service Learning 14, no. 2 (2008), 50-65.

23 Clifford, "Talking About Service-Learning."

${ }^{24} \mathrm{H}$. Burth, "The Contribution of Service-Learning Programs to the Promotion of Engagement and Political Participation: A Critical Evaluation," Citizenship, Social and Economics Education 15, no. I (2016): 58-66; D. Butin, "Dreaming of Justice: Critical Service-Learning and the Need to Wake Up," Theory into Practice 54, no. 1 (2015): $5-10$.

${ }^{25}$ M. Asghar and N. Rowe, "Reciprocity and Critical Reflection as the Key to Social Justice in Service Learning: A Case Study," Innovations in Education and Teaching International 54, no. 2 (2017): 117-125; M. Latta, T. M. Kruger, L. Payne, L. Weaver, and J. L. VanSickle, "Approaching Critical Service-Learning: A Model for Reflection on Positionality and Possibility," Journal of Higher Education Outreach and Engagement 22, no. 2 (2018): 31-55; Mitchell, "Traditional vs. Critical Service-Learning." 
change. ${ }^{26}$ Mitchell identifies "social change orientation, working to redistribute power, and developing authentic relationships" 27 as common elements to distinguish critical service-learning from traditional servicelearning. Learning outcomes are to acknowledge the unequal global power dynamics, reflect on students' own place in the global world, and ultimately address social injustice. ${ }^{28} \mathrm{~A}$ broader analysis of power within service-learning is key to understanding how hierarchy hinders the acknowledgment or problematization of inequality in critical servicelearning. ${ }^{29}$

It is also important to note that social inequality is not perpetuated solely by the side of the students who do the service from mostly the North or the more privileged, but also reinforced by the community members who receive service. There is danger in dependency-oriented service based on a savior mentality which reflects a negative view of the service recipient as dependent and incapable. ${ }^{30}$ However, Grain et al. indicate that the framing white international students as givers-of-knowledge and the catalysts of positive change was prevalent in local communities in Africa despite international service-learning programming that prepares students through decolonizing frameworks and critical self-reflection in Canada. ${ }^{31}$ The white supremacy imposed by colonialism and the postcolonial vestiges of white privilege continue to reveal in diverse ways in the process of service-learning, regardless of how much one attempts to decolonize its intent.

To overcome this dichotomous tension of colonizer/colonized or service-giver/service-taker, a concept of solidarity has been suggested.

${ }^{26}$ Asghar and Rowe, "Reciprocity and Critical Reflection as the Key to Social Justice in Service Learning"; F. Atkas, K. Pitts, J. C. Richards, and I. Silova, "Institutionalizing Global Citizenship: A Critical Analysis of Higher Education Programs and Curricula," Journal of Studies in International Education 21, no. 1 (2017): 65-80.

${ }^{27}$ Mitchell, "Traditional vs. Critical Service-Learning," 62.

${ }^{28}$ Atkas, Pitts, Richards, and Silova, "Institutionalizing Global Citizenship."

${ }^{29}$ T. D. Mitchell, D. M. Monahue, and C. Young-Law, "Service Learning as a Pedagogy of Whiteness," Equity and Excellence in Education 45, no. 4 (2012): 612-629.

${ }^{30}$ Brown, Wymer, and Cooper, "The Counter-Normative Effects of Service-Learning."

${ }^{31}$ K. Grain, T. Katumba, D. Kirumira, R. Nakasiita, S. Nakayenga, E. Nankya, V. Nteza, and M. Sssegawa, "Co-constructing Knowledge in Uganda: Host Community Conceptions of Relationships in International Service-Learning," Journal of Experiential Education 42, no. 1 (2019): 22-36. 
Tapia defines solidarity as actions that are developed in conjunction with the community and not for it. ${ }^{32}$ Solidarity is a way to resist colonial logics because it requires the configuration of new ways of being, interacting, and learning, which together emphasize the collective, the reciprocal, and mutual, rather than individualistic notions of the self. ${ }^{33}$ Santiago-Ortiz notes that "service" implies a hierarchical relationship from the outset and that "solidarity" opens the door for epistemic disobedience that transgresses colonialist understandings of knowledge and relationships. ${ }^{34}$ The concept of solidarity suggests that one should tackle social inequality and social justice beyond the hierarchical analysis of social groups and build a more horizontal and solidary community-university partnership.

Although we still lack sufficient and compelling evidence to suggest the types and depth of lessons learnt from service-learning programs in Asia as reference to the rich knowledge accumulation in North and South America, the next section will examine students' learning outcomes of international service-learning in and out of Japan and in particular in the context of International Christian University, lessons of which could be extended to other universities in Asia.

\section{ICU's INTERNATIONAL SERVICE-LEARNING AND ITS IMPACT ON STUDENTS}

International Christian University (ICU) is the leading liberal arts college in Japan with approximately 2800 students and 152 full-time faculty members with the distinctive feature of $40 \%$ of faculty coming from overseas and $30 \%$ being female professors. Its founding philosophy was supranational and derived from deep reflection on World War II. ${ }^{35}$ Democratic

${ }^{32}$ M. N. Tapia, “Academic Excellence and Community Engagement: Reflections on the Latin American Experience," in Higher Education and Civic Engagement: Comparative Perspectives, edited by L. Mcllrath, A. Lyons, and R. Munck (New York: Palgrave Macmillan, 2012), 193.

${ }^{33}$ Clifford, "Talking About Service-Learning"; A. Santiago-Ortiz, "From Critical to Decolonizing Service-Learning: Limits and Possibilities of Social Justice-Based Approaches to Community Service-Learning," Michigan Journal of Community Service Learning 25, no. 1 (2019): 43-54.

${ }^{34}$ Santiago-Ortiz, "From Critical to Decolonizing Service-Learning."

${ }^{35}$ M. Nishimura, "Liberal Arts for a New Japan: The Case of the International Christian University," in Liberal Arts Education and Colleges in East Asia: Possibilities and Challenges 
Table 7.1 ICU's service-learning program development phase

\begin{tabular}{|c|c|}
\hline Phase & Development \\
\hline $\begin{array}{l}\text { 1. Primary phase (1996-1998): } \\
\text { International exploration }\end{array}$ & $\begin{array}{l}\text { Introduced the practicum course } \\
\text { entitled "international internship" }\end{array}$ \\
\hline $\begin{array}{l}\text { 2. Second phase (1999-2005): } \\
\text { College-wide expansion and } \\
\text { institutionalization }\end{array}$ & $\begin{array}{l}\text { Expanded a service-learning } \\
\text { college-wide course, established the } \\
\text { Service-Learning Center in 2002, } \\
\text { initiated the Service-Learning Asia } \\
\text { Network (SLAN), and published the } \\
\text { monograph series on service-learning }\end{array}$ \\
\hline $\begin{array}{l}\text { 3. Third phase (2006-2008): } \\
\text { International partnership development }\end{array}$ & $\begin{array}{l}\text { Developed the cohort international } \\
\text { service-learning model programs in Asia } \\
\text { and Africa }\end{array}$ \\
\hline $\begin{array}{l}\text { 4. Fourth phase (2009-2015): } \\
\text { Standardization and routinization }\end{array}$ & $\begin{array}{l}\text { Standardized and routinized the cohort } \\
\text { international service-learning model } \\
\text { programs }\end{array}$ \\
\hline $\begin{array}{l}\text { 5. Fifth phase (2016-present): } \\
\text { Enbancing reciprocity in partnership }\end{array}$ & $\begin{array}{l}\text { Developed an inbound service-learning } \\
\text { program called Japan Summer } \\
\text { Service-Learning (JSSL) in } 2016 \text { to } \\
\text { enhance reciprocity in partnership }\end{array}$ \\
\hline
\end{tabular}

ideals have formulated ICU's unique organizational culture reflected in the respect for individuals, their freedom to develop, their rights in society, and students' rights to open participation and interaction in all classroom activities. ICU also enjoys an international and intercultural outlook of the student population with $10 \%$ being international students and $25 \%$ being returnees from abroad (i.e. Japanese students who spent their childhood overseas).

ICU is the pioneer of introducing a Service-Learning Program in Japan. The service-learning course was introduced in 1999 for the first time in Japan. As shown in Table 7.1, ICU followed five phases of development. It established the Service-Learning Center in 2002 and initiated the Service-Learning Asia Network (SLAN) with 8 universities and 1 non-profit organization in Asia including representation from China, Hong Kong, India, Indonesia, the Philippines, South Korea, and Thailand. International service-learning is a form of experiential education

in the Global Age, edited by I. June, M. Nishimura, and T. Sasao (Singapore: Springer, 2016), 51-62. 
that integrates community-led service activities, academic instruction, and intentional reflection in an international or cross-cultural setting. ${ }^{36}$

In this section, we illustrate two recent studies carried out by the coordinators at the Service-Learning Center of ICU to examine the characteristics of learning outcomes in light of the existing literatures and their challenges.

\section{Japan Summer Service-Learning (JSSL) in Pursuit of Stakeholders' Reciprocity}

After working with SLAN partners for two decades, ICU, together with the Center for Community Engagement of Middlebury College, one of our US partner institutions, developed an inbound service-learning program called the Japan Summer Service-Learning (JSSL) in 2016 to enhance reciprocity in partnership and to overcome the linear development model and savior complex mentality. JSSL is a four-week, community connected, cohort program in the summer tailored for incoming students from the SLAN partner universities, Middlebury College, and ICU. The participating students deepen their understanding of Japanese society through serving together in the local communities both in the urban and rural areas. In 2018, a total of 14 students participated: 6 students from SLAN partner universities (2 students each from Silliman University, the Philippines, Union Christian College, India, Assumption University, Thailand), 4 from Middlebury College, and 4 from ICU.

To explore and examine how the JSSL program has functioned to improve reciprocity, we applied the SOFAR model. ${ }^{37}$ Reciprocity does not take place just between the two entities such as the partner university and ICU, but it can take place in various forms, such as between the students and the beneficiary, community organizations, between the practitioners of institutions and the staff of receiving organizations. The SOFAR model delineated the structure of relationships in sub-sets and it is useful to articulate mutual relationships between the five stakeholders. It is a structural framework for relationships among the five constituencies, namely Students, Organizations in the community, Faculty,

\footnotetext{
${ }^{36}$ Robbin D. Crabtree, "Theoretical Foundations for International Service-Learning," Michigan Journal of Community Service Learning 15, no. 1 (Fall 2008): 18-36.

${ }^{37}$ R. C. Bringle, P. Clayton, and M. Price, "Partnerships in Service Learning and Civic Engagement," Partnerships 1, no. 1 (2009): 1-20.
} 
Administrators on campus, Residents in the community. ${ }^{38}$ It demonstrates a total of ten dyadic relationships between the five constituencies.

With the SOFAR model, we examined (1) how the JSSL program has contributed to building reciprocity among the stakeholders, and (2) what type of evaluation the program needs for further development to ensure reciprocity. We used qualitative data which reflects the voices of the participants and partner institutions. These data include ( 1 ) evaluations from student participants of JSSL, (2) semi-structured interviews with the JSSL coordinator, and (3) written reports submitted by ICU students after JSSL for 3 credits. By applying JSSL into the SOFAR model, we found three types of relationships with students as below to be more prominent in the JSSL program.

Students and Administrators (Dyad Numbered as 1)

Although the role of administrators is to coordinate the program, the relationship between students and administrators tends to become more than "communication with each other" 39 as the program proceeds. For example, one of the participants commented:

I received so much hospitality from people around us, including SLC (Service-Learning Center) staffs....Those experiences brought me to a completely different world from what I had seen a month ago, made us able to have a connection with community people, and made me open minded.

Multicultural interaction enriches communication and generates multiple perspectives. The interaction between Asian students and Middlebury staffs also enables students to learn reflections from a different perspective in their rich experiences.

\section{Community Organizations and Students (Dyad Numbered as 9)}

During summer, JSSL participants have service activities in both Mitaka city, Tokyo and Tenryu village, Nagano Prefecture. In Mitaka, students can design their activities for about three weeks. In the past programs,

\footnotetext{
${ }^{38}$ Bringle, Clayton, and Price, "Partnerships in Service Learning and Civic Engagement," 5 .

${ }^{39}$ Bringle, Clayton, and Price, "Partnerships in Service Learning and Civic Engagement," 4 .
} 
they engaged in community service activities at several institutions such as agricultural associations, nursing homes for the elderly, and elementary schools. Tenryu village is a rural and mountainous village where the elderly accounts for more than $60 \%$ of the population. The relationship with the local population was initiated by ICU students who did a community service-learning in the village in summer 2015. After their service activity, they thought a way to maintain their relationship and started the JSSL program together. This is an example of coordinating or joint planning with student and community organizations.

Furthermore, a few students' comments showed their appreciation to have inter-generational and various exchanges that are rare in daily life as follows:

- I was able to have a multi-generational exchange.

- I had such a good experience with JSSL program, for example, volunteering at facility for elderly people and elementary school in Mitaka and staying Tenryu village.

- Cooperating with not only JSSL members but also community people was the most meaningful.

\section{Students and Community Residents (Dyad Numbered as 6)}

For both ICU and visiting students, the interaction with the Tenryu village host community through home visits and homestays was one of the memorable activities of the participants. During their stay in the village, they learned to communicate with each other better despite their linguistic and cultural differences. They also had an opportunity to listen to the elder residents' narrative of the history of the village or story of World War II. These experiences indicate that they reached a deep level of communication with each other, although their interaction might remain at a transactional level. One student commented:

The most meaningful aspect of the programme, according to me, is the opportunity extended to us to experience the community rural life by interacting with the people belonging to several communities. This interaction helped understand several things including the fact that linguistic and cultural differences are not any barrier to human love and interaction. The love extended to us from those people helped me understand the importance of caring for others and the need to be more compassionate...the 
chance to interact with people freely proved to be the most meaningful aspect of the program unto me.

As such, we could identify the multilevel stakeholder relationships and their reciprocity. It was confirmed that JSSL contains good relationship with three dyads. It became apparent that ICU fosters students' learning and well-being and maintains relationships well with community organizations for the sake of running the program smoothly.

For the rest of seven dyads, however, there were not much data available to confirm. Anecdotal evidence suggests that there exists a good relationship between faculty and administrators (dyad numbered 10) and community organizers and community residents (dyad numbered 3) as it would have been impossible to carry out the successful JSSL program without such relationships. Nevertheless, much has to be done to improve reciprocity with community organizers and faculty.

Two distinctive observations stood out beyond the existing framework. First, as JSSL had internationally mixed groups with various cultural backgrounds, students appreciated the opportunity to learn from different perspectives of the service activities. The multicultural reciprocal learning among the student groups generated in JSSL added a new reciprocity to the service-learning program framework. For instance, one student deepened their insight on localism by associating with community residents and other students from overseas:

Advancement of globalization made our world borderless, which made our intercultural exchange possible with abundant merits through such networks. However, its downside is the lost concept of localization.... Coexisting with nature, respect for culture and tradition, spirit of mutual support are missing yet critical elements for us. Linking with people, community, and local network may reduce inequality and co-create equal and peaceful society in the future.

Others simply appreciate the new discovery of what was otherwise taken for granted:

By looking at the reaction when foreign students face Japanese culture which was new to them I was made to think of it (such as "why" and "how come"). This cannot be experienced without participating in the JSSL program. 
For me, it (the most meaningful aspect of JSSL) was definitely working in a multi-cultural environment. It was incredibly beneficial for me to have this experience. I feel like I have much more confidence with working -very closely- with people from all around the world. I learned how to communicate with strangers, how to be a better listener, and I learned how to think beyond my own perspective.

Second, students repeatedly mentioned their learning experiences about themselves through interactions with other students and local community residents, and being in a different environment. Revisiting a concept of self is not highlighted in the SOFAR model, but is reported in other service-learning programs in Asia. ${ }^{40}$ One student reflected on his/her own being:

My overall experience with service learning was a life-changing experience. It gave me a new perspective not just in service-learning but with the different perspective in life. It gave me the appreciation of living life in an orderly manner and being conscious with other people just by observing the Japanese people's lifestyle. It gave me the chance of gaining selfindependence by just living away from our home. I have also learned the importance of being active in helping and not to be apathetic in activities in the community... and the importance of living a much simpler life. I will never forget all of these moments that I had.

Another student shifted his/her initial expectation from exploring a new country to exploring oneself:

My experiences at the JSSL had been the most valuable experience to me as an individual as well as a societal being. My initial thoughts about the program was that I could explore a foreign country for the first time, learn about its culture and get to know a whole lot of people from various walk of life. But looking back now at the end of the program, I feel that this was more than just exploring a new country; it was exploring myself and opening myself to a whole lot of new perspectives.

${ }^{40}$ Yang et al., "The Role of International Service-Learning in Facilitating Undergraduate Students' Self-Exploration.” 
While JSSL has enhanced reciprocity, engagement, connection to the local community, and inclusivity and participation at the multicultural levels, reciprocity with and engagement of community organizers and faculty seem to be overlooked at least from the students' learning process and reflection. Furthermore, critical perspective on and structural analysis of social inequality and problems are missing from their reflection.

\section{Learning Outcome of International Service-Learning}

Kuronuma made research on the characteristics of ICU's service-learning using the Eyler and Giles Indicator model. ${ }^{41}$ The aim of the research was to compare the program characteristics and outcomes of service-learning between the US and Japanese universities and to extract distinctive outcome indicators of ICU's international service-learning programs.

Qualitative text analysis was made on 60 students' papers from the first three phases of ICU's development of international service-learning outlined in Table 7.1 (i.e. between 1996 and 2008). Those reports were broken down into 205 written description data for coding.

From the results of qualitative text analysis of students' papers, there appeared some distinctive learning outcomes of ICU that are different from Eylers and Giles' indicator. They include students' career choices and deep consideration of what the service is. In the primary phase (19961998), the influence of service-learning on students' career choice was more apparent than in other phases because the course was offered as an "internship" closely linked with career development. Deep consideration of meaning of service was more evident in the second and third phases. In the second phase, service-learning became the university-wide curriculum that included introduction to service-learning, preparation, and reflection courses. In the second and third phases, service-learning courses focused on the definition and moral reasoning of service and learning processes. As a matter of fact, it was between these two phases when ICU published the first three volumes of the monograph entitled The Service-Learning Studies Series to explore an academic and institutional identity of servicelearning. In these series, there was much discussion of the connection

${ }^{41}$ A. Kuronuma, "Learning Outcomes of International Service-Learning in the Japanese Context: The Case of International Christian University" (Paper, 7th Asia-Pacific Regional Conference on Service Learning, Singapore, June 2019); J. Eyler and D. E. Giles Jr., Where's the Learning in Service-Learning? (San Francisco: Jossey-Bass, 1999). 
between service-learning and Christian philosophy, experiential learning pedagogies, and whole-personal development. ${ }^{42}$

In contrast, the element that was commonly found in service-learning practices in the United States but not in ICU was citizenship. While citizenship is a major and critical outcome of service-learning in American higher education, it was less prominent in ICU. ICU's approach to service-learning focused on students' whole-personal development with Christian philosophy and there was comparatively less discussion or inquiry of social justice, social change, or democracy. Again, critical perspectives of service-learning that emerged in the international sphere in the late 2000s did not appear in any curricular intent, students' reports, or faculty-led monographs.

Overall findings show that ICU's service-learning in the first three phases focused on the content and operation of service activities, their quality improvement as pedagogy, and diversification of programs to create more opportunities for students to serve others. Such characteristics influenced the outcome to nurture "personal development," "perspective transformation," "interpersonal development," "avoiding stereotyping," "tolerance," and so on. While ICU distinctively shows the characteristics of deep conceptions of the meaning of doing service for others, "others" for or with whom we serve was vaguely defined. Positionality of students remained unquestioned and the programs did not clearly address social inequality or social justice issues.

\section{Discussion: Missing Link Between Moral Awareness and Civic Engagement}

The outcomes of ICU's service-learning in the previous section reveal that students learned much about their self-conceptions, obtained intercultural communication skills and competencies, and achieved personal development. Some received the intellectual stimulation to investigate underlying social issues, while others were able to revisit their own culture and social problems from a comparative lens in interacting with international students or communities in different countries.

42 International Christian University (ICU), Introduction to Service-Learning (Tokyo: ICU, 2004); ICU, Why Do People Do Service? (Tokyo: ICU, 2005); ICU, Invitation to Service-Learning (Tokyo: ICU, 2008). 
Nevertheless, critical perspectives were missing from the programs. The design of the programs almost entirely focused on students' learning of the self and society. The roles of community and faculty in promoting social and intellectual inquiry with students were negligent. Such design did not allow students to convey their thinking beyond personal experience to refer to the structural problems and strategic communication beyond cultural exchange. Reciprocity is depoliticized whereby everything that students see and feel are presented in such a way that students are supposed to receive them in the form of learning rather than question, reinterpret, challenge, and cocreate them with the community. Students perceive social problems, especially in a rural village or in a foreign country, as a "social problem" detached from them or where students did not perceive themselves as part of the change agent. This stance echoes with demonstrating their desire to help "the disadvantaged" in ways that do not require them to acknowledge or address structural inequality. ${ }^{43}$

Furthermore, the way volunteer opportunities are organized in Japan is worth noting in thinking about civic engagement with a critical lens. Local government organizations, community organizations, and nonprofit organizations usually post an advertisement for volunteer opportunities on their homepage, in public papers, and through universities. Students simply "apply" for the volunteer posts that match their interests. Community in this sense is the opportunity-giver and students are opportunity-taker, while students are service-giver and communities are service-taker. In this highly institutionalized and organized context of reciprocity, the concept of a joint change maker or solidarity is hard to grow. In the "General Education on Service-Learning" course at ICU, where students were required to do service for 18 hours in 9 weeks, one student asked how a part-time job and service were different apart from the presence/absence of monetary rewards. This question addresses students' passive perception of “opportunity-taker" to volunteer without questioning their status quo or pursuing any social change. This is the very concern critics have raised about institutionalized volunteer and learning opportunity. ${ }^{44}$

${ }^{43}$ Mitchell, Monahue, and Young-Law, "Service Learning as a Pedagogy of Whiteness."

${ }^{44}$ T. Stanton, "Half Full or Half Empty...Who Knows?: Reflections on Forty-Five Years in Service Learning's Trenches," in Where's the Wisdom in Service-Learning? edited by R. Shumer (Charlotte, NC: Information Age Publishing, 2019), 81-92. 
There is another contextual lens that we can offer here with regards to positionality of students. In East Asia, individuals are expected to adopt Confucian values and social norms, such as respecting authoritative persons' decisions, conforming to the majority's views, and giving priority to collective over personal interests. ${ }^{45}$ In Japan, people often use the term "gakusei" (student as a learning person) and "shakaijin" (a member of the society who contributes to the society mostly by participating in the labor market) to draw a line to maintain the status quo. Such a social norm suggests that a student is someone who has not yet entered a "society" to make a tangible contribution, thus substantially reinforces a notion of students' immaturity and limited control over what they can do. The comment we received from students in the General Education Course presents the case in point:

As a volunteer, I was told to guide the participants to respective seats at the event. A disabled person in the wheelchair came and needed an extra space. I found the need to create the space for it but felt that I should not just do it without permission from the event organizer. I was not sure how much I, as a student volunteer, can suggest a change of the planned operation or do something beyond what I was told to do.

In the hierarchical society by age, gender, social status, etc., students' spontaneity and self-efficacy as citizens are hard to grow. The literature on global citizenship education in East Asia also suggests that students tend to do well in exams to reproduce their knowledge on global citizenship, but that it is harder to translate that knowledge into behavioral change. ${ }^{46}$ Service-learning tends to encourage students to revisit their conception of self, but whether this revision will transform their behavior is potentially a critical challenge.

Faculty and staff who design service-learning may also need transformation if we are to seek more intellectual rigor and incorporation of social change and solidarity ideals into service-learning beyond

${ }^{45}$ M. Yang, B. Webster, and M. Prosser, "Travelling a Thousand Miles: Hong Kong Chinese Students' Study Abroad Experience," International Journal of Intercultural Relation 35, no. 1 (2011): 69-78.

${ }^{46}$ H. R. Sim, "Global Citizenship Education in South Korea Through Civil Society Organizations: Its Status and Limitations," Asian Journal of Education 17 (2016): 107129. 
dichotomous reciprocity of service-provider/service-taker or opportunitygiver/opportunity-taker. In an aging society with a declining universitygoing population and at the universalization stage of higher education, ${ }^{47}$ Japanese universities (and parents) are more and more over-protective for students and deal with them as a consumer and recipient of higher education services, which reinforces students' sense of immaturity and helplessness. Such a vicious circle should be overcome by generating more students' autonomy and responsibilities in service-learning so that they can obtain the sense of self as one who can transform a society. As Jacoby suggests, we may need a brave space for students on campus in addition to a safe space to empower and enhance their civic engagement. ${ }^{48}$

In order for learning outcomes of service-learning to sustain and to lead to behavioral change, its design should focus more on student inquiry of social issues (Why do we do service?) and their positionality and awareness of the social structure that affects their status quo as well as those oppressed/disadvantaged (What is the problem surrounding us and how can we approach it?). International service-learning challenges one's epistemology or deeply embedded beliefs and knowledge about the world around us. ${ }^{49}$ Such epistemological challenges should include our revision of the socially constructed self-concept as "student" in the Asian context.

With the tendency of focusing on Western practicality and growing competition in higher education in Asia, educators at the university level need to stop and contemplate their role in nurturing civically engaged students and scholars. Especially in hierarchical societies within Asia, it may be a long way to go to transform our mind-set from someone who receives/gives service and skillsets to someone who jointly works for a co-created purpose. The United Nation's Sustainable Development Goals (SDGs) (2015-2030) suggest that the concept of modern development should be revisited with the perspectives of global sustainability and social inclusion. Equity, inclusion, and quality of education are of primary importance outlined in SDG 4. Departing from an elusive quest of

${ }^{47}$ M. Trow, Problems in the Transition from Elite to Mass Higher Education (Berkeley: Carnegie Commission on Higher Education, 1973).

48 B. Jacoby, "The New Student Activism: Supporting Students as Agents of Social Change," Journal of College and Character 18, no. 1 (2017): 1-8.

${ }^{49}$ A. M. Oberhauser and R. Daniels, "Unpacking Global Service-Learning in Developing Contexts: A Case Study from Rural Tanzania," Journal of Higher Education Outreach and Engagement 21, no. 4 (2017): 139-170. 
catch-up mind-set with the West, we need to wrestle with the question of how higher education institutions can envision inclusive and equitable quality education for all and situate our role in enhancing social equality and inclusion as an earnest challenge of the twenty-first century.

\section{BIBLIOGRAPHY}

Ananiadou, K., and M. Claro. "21st Century Skills and Competencies for New Millennium Learners in OECD Countries." OECD Education Working Papers No. 41, 2009.

Andersson, P. "Inequality in Asia and the Pacific." Presentation at the Interregional Expert Group Meeting on Placing Equality at the Center of Agenda 2030, Santiago, June 2018. https://www.cepal.org/sites/default/ files/presentations/sl_3._pandersson.escap_.pdf.

Asghar, M., and N. Rowe. "Reciprocity and Critical Reflection as the Key to Social Justice in Service Learning: A Case Study." Innovations in Education and Teaching International 54, no. 2 (2017): 117-125.

Atkas, F., K. Pitts, J. C. Richards, and I. Silova. "Institutionalizing Global Citizenship: A Critical Analysis of Higher Education Programs and Curricula." Journal of Studies in International Education 21, no. 1 (2017): 65-80.

Brewster, K. R. "Transformative and Transformed: Examining the Critical Potential of Service-Learning Positional Identities." Equity \& Excellence in Education 51, nos. 3-4 (2018): 347-361.

Bringle, R. G., P. Clayton, and M. Price. "Partnerships in Service Learning and Civic Engagement." Partnerships 1, no. 1 (2009): 1-20.

Bringle, R. G., and J. A Hatcher. "A Service-Learning Curriculum for Faculty." Michigan Journal of Community Service Learning 2, no. I (1995): 112-122.

Brown, M. A., J. D. Wymer, and C. S. Cooper. "The Counter-Normative Effects of Service-Learning: Fostering Attitudes Toward Social Equality Through Contact and Autonomy." Michigan Journal of Community Service Learning 23, no. 1 (2016): 37-44.

Buchler, J. "Reconstruction in the Liberal Arts." In A history of Columbia College on Morningside, edited by D. C. Miner. New York: Columbia University Press, 1954.

Burth, H. "The Contribution of Service-Learning Programs to the Promotion of Engagement and Political Participation: A Critical Evaluation." Citizenship, Social and Economics Education 15, no. 1 (2016): 58-66.

Butin, D. "Dreaming of Justice: Critical Service-Learning and the Need to Wake Up." Theory into Practice 54, no. l (2015): 5-10.

Chan, K., E. Ng, and C. C. Chan. "Empowering Students Through ServiceLeaning in a Community Psychology Course: A Case in Hong Kong." Journal of Higher Education Outreach and Engagement 20, no. 4 (2016): 25-35. 
Chen, S. J. "Shifting Patterns of Student Mobility in Asia." Higher Education Policy 25, no. 2 (2012): 207-224.

Chopp, R. "Remaking, Renewing, Reimagining the Liberal Arts College Takes Advantage of Change." In Remaking College: Innovation and the Liberal Arts, edited by R. Chopp, S. Frost, and D. H. Weiss, 13-24. Baltimore: Johns Hopkins University Press, 2014.

Clifford, J. "Talking About Service-Learning: Product or Process? Reciprocity or Solidarity?" Journal of Higher Education Outreach and Engagement 21, no. 4 (2017): 1-13.

Conner, J., and J. Erickson. "When Does Service-Learning Work? Contact Theory and Service-Learning Courses in Higher Education." Michigan Journal of Community Service Learning 23, no. 2 (2017): 53-65.

Eyler, J., and D. E. Giles Jr. Where's the Learning in Service-Learning? San Francisco: Jossey-Bass, 1999.

Furco, A. "Foreword." In Problematizing Service-Learning: Critical Reflections for Development and Action, edited by T. Stewart and N. Webster, ix-xi. Charlotte: Information Age, 2011.

Godwin, K. A. "The Global Emergence of Liberal Education: A Comparative and Exploratory Study." PhD diss., Boston College, 2013. https://dlib.bc. edu/islandora/object/bc-ir:104384.

—. "The Worldwide Emergence of Liberal Education." International Higher Education 79 (2015): 2-4.

Grain, K., T. Katumba, D. Kirumira, R. Nakasiita, S. Nakayenga, E. Nankya, V. Nteza, and M. Sssegawa. "Co-constructing Knowledge in Uganda: Host Community Conceptions of Relationships in International Service-Learning." Journal of Experiential Education 42, no. 1 (2019): 22-36.

Hutchins, R. M. The Higher Learning in America. New Haven: Yale University Press, 1968.

International Christian University. Introduction to Service-Learning. Tokyo: International Christian University, 2004.

- Invitation to Service-Learning. Tokyo: International Christian University, 2008.

- Why Do People Do Service? Tokyo: International Christian University, 2005.

Jacoby, B. "The New Student Activism: Supporting Students as Agents of Social Change." Journal of College and Character 18, no. 1 (2017): 1-8.

King, H. C. "What the College Stands for." Association of American Colleges Bulletin III, no. 1 (1917): 24.

Kuronuma, A. "Learning Outcomes of International Service-Learning in the Japanese Context: The Case of International Christian University." Paper presented at the 7th Asia-Pacific Regional Conference on Service Learning, Singapore, June 2019. 
Latta, M., T. M. Kruger, L. Payne, L. Weaver, and J. L. VanSickle. "Approaching Critical Service-Learning: A Model for Reflection on Positionality and Possibility." Journal of Higher Education Outreach and Engagement 22, no. 2 (2018): 31-55.

Lee, J., and H. Lee. "Human Capital and Income Inequality." ADBI Working Paper Series No. 810, Asian Development Bank Institute, Tokyo, 2018.

Logan, J., and J. Curry. "A Liberal Arts Education: Global Trends and Challenges." Christian Higher Education 14, nos. 1/2 (2014): 66-79.

Meiklejohn, A. The Liberal College. Boston: Marshall Jones, 1920.

Mitchell, T. D. "Traditional vs. Critical Service-Learning: Engaging the Literature to Differentiate Two Models." Michigan Journal of Community Service Learning 14, no. 2 (2008): 50-65.

Mitchell, T. D., D. M. Monahue, and C. Young-Law. "Service Learning as a Pedagogy of Whiteness." Equity \& Excellence in Education 45, no. 4 (2012): 612-629.

Mok, K. H., and K. M. Yu. Internationalization of Higher Education in East Asia: Trends of Student Mobility and Impact on Education Governance. New York: Routledge, 2014.

Nishimura, M. "Liberal Arts for a New Japan: The Case of the International Christian University." In Liberal Arts Education and Colleges in East Asia: Possibilities and Challenges in the Global Age, edited by I. June, M. Nishimura, and T. Sasao, 51-62. Singapore: Springer, 2016.

Oberhauser, A. M., and R. Daniels. "Unpacking Global Service-Learning in Developing Contexts: A Case Study from Rural Tanzania." Journal of Higher Education Outreach and Engagement 21, no. 4 (2017): 139-170.

OECD. The Future of Education and Skills: Education 2030. Paris: OECD, 2018.

Pascarella, E. T., G. C. Wolniak, T. A. D. Seifert, T. M. Cruce, and C. F. Blaich. "Liberal Arts Colleges and Liberal Arts Education." ASHE Higher Education Report 31, no. 3 (2005): 1-146.

Rowen, C. "So Much More Than Salary: Outcomes Research in Liberal Arts." New Direction for Institutional Research 169 (2016): 51-60.

Sadovnik, A. R., ed. Sociology of Education: A Critical Reader. 2nd ed. New York: Routledge, 2010.

Santiago-Ortiz, A. "From Critical to Decolonizing Service-Learning: Limits and Possibilities of Social Justice-Based Approaches to Community ServiceLearning." Michigan Journal of Community Service Learning 25, no. 1 (2019): $43-54$.

Shah, M., and D. T. N. Quyen, eds. The Rise of Quality Assurance in Asian Higher Education. Cambridge: Chandos Publishing, 2017.

Sim, H. R. "Global Citizenship Education in South Korea Through Civil Society Organizations: Its Status and Limitations." Asian Journal of Education 17 (2016): 107-129. 
Stanton, T. "Half Full or Half Empty...Who Knows?: Reflections on Forty-Five Years in Service Learning's Trenches." In Where's the Wisdom in ServiceLearning? edited by R. Shumer, 81-92. Charlotte, NC: Information Age Publishing, 2019.

Summerscales, W. Affirmation and Dissent. New York: Teachers College Press, 1970.

Tapia, M. N. “Academic Excellence and Community Engagement: Reflections on the Latin American Experience." In Higher Education and Civic Engagement: Comparative Perspectives, edited by L. Mcllrath, A. Lyons, and R. Munck, 187-203. New York: Palgrave Macmillan, 2012.

Trow, M. Problems in the Transition from Elite to Mass Higher Education. Berkeley: Carnegie Commission on Higher Education, 1973.

Yang, M., B. Webster, and M. Prosser. "Travelling a Thousand Miles: Hong Kong Chinese Students' Study Abroad Experience.” International Journal of Intercultural Relation 35, no. 1 (2011): 69-78.

Yang, M., L. Y. Y. Luk, B. J. Webster, A. W. Chau, and C. H. K. Ma. "The Role of International Service-Learning in Facilitating Undergraduate Students' SelfExploration." Journal of Studies in International Education 20, no. 5 (2016): 416-436.

Yang, R. "The East-West Axis? Liberal Arts Education in East Asian Universities." In Liberal Arts Education and Colleges in East Asia: Possibilities and Challenges in the Global Age, edited by I. June, M. Nishimura, and T. Sasao, 27-38. Singapore: Springer, 2016.

Yonezawa, A., and M. Nishimura. "Revisiting Key Values, Roles, and Challenges of Liberal Arts Education in East Asia." In Liberal Arts Education and Colleges in East Asia: Possibilities and Challenges in the Global Age, edited by I. June, M. Nishimura, and T. Sasao, 125-136. Singapore: Springer, 2016. 
Open Access This chapter is licensed under the terms of the Creative Commons Attribution 4.0 International License (http://creativecommons.org/licenses/ by $/ 4.0 /$ ), which permits use, sharing, adaptation, distribution and reproduction in any medium or format, as long as you give appropriate credit to the original author(s) and the source, provide a link to the Creative Commons license and indicate if changes were made.

The images or other third party material in this chapter are included in the chapter's Creative Commons license, unless indicated otherwise in a credit line to the material. If material is not included in the chapter's Creative Commons license and your intended use is not permitted by statutory regulation or exceeds the permitted use, you will need to obtain permission directly from the copyright holder.

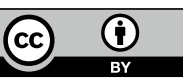

